\title{
Chemodiversity of Essential Oils in Piper L. (Piperaceae) Species from Marambaia Island, Rio de Janeiro-RJ, Brazil
}

a Universidade do Estado do Rio de Janeiro, Instituto de Biologia, Pós-graduação em Biologia Vegetal, Maracanã, CEP 20550013. Rio de Janeiro-RJ, Brazil.

b Departamento de Produtos Naturais, Farmanguinhos, Fundação Oswaldo Cruz, Manguinhos, CEP 21041-250, Rio de Janeiro-RJ, Brazil.

${ }^{\mathrm{C}}$ Centro de Responsabilidade Socioambiental do Instituto de Pesquisas Jardim Botânico do Rio de Janeiro, Jardim Botânico, CEP 22460030, Rio de Janeiro-RJ, Brazil

d Diretoria de Pesquisa do Instituto de Pesquisas Jardim Botânico do Rio de Janeiro, Jardim Botânico, CEP 22460-030, Rio de Janeiro-RJ, Brazil

\section{*E-mail: davysonmoreira@ hotmail.com}

Recebido: 22 de Março de 2021

Aceito: 22 de Março de 2021

Publicado online: 6 de Outubro de 2021

\author{
Quimodiversidade de Óleos Essenciais em Espécies de Piper L. (Piperaceae) \\ da Restinga da Ilha da Marambaia, Rio de Janeiro-RJ, Brasil
}

Rudá Antas Pereira, ${ }^{a}$ Ygor Jessé Ramos, a,b,c George Azevedo de Queiroz, ${ }^{c}$ Elsie Franklin Guimarães, ${ }^{d}$ Anna Carina Antunes e Defaveri, ${ }^{c}$ Davyson de Lima Moreira ${ }^{a, b, *}$ (D)

\begin{abstract}
This study aimed to determine the pattern of chemodiversity from the chemical composition of the leaf essential oil (EO) of ten species and two varieties of Piper (Piper amalago L.; P. amplum Kunth; $P$. anisum (Spreng.) Angely; P. arboreum Aubl. var. arboreum; $P$. arboreum var. hirtelum Yunck.; $P$. diospyrifolium Kunth; P. divaricatum G. Mey.; P. gaudichaudianum Kunth; P. lepturum (Kunth) C.DC. var. lepturum; P. lepturum var. angustifolium (C.DC.) Yunck.; P. mollicomum Kunth and P. vicosanum Yunck.) collected in the Marambaia Island, Rio de Janeiro (Brazil). The main compounds identified in the EO were Linalool, Guaiol, 1-Butyl-3,4-methylenedioxybenzene, iso-Leptospermone, $\alpha$-Eudesmol, trans-Nerolidol, Germacrene D, $\beta$-Elemene, 7-epi- $\alpha$-Selinene, 1,8-Cineole, $\alpha$-Eudesmol, $\alpha$-Copaene, trans- $\gamma$-Bisabolene, Bicyclogermacrene and $\beta$-Bisabolol. In the chemometric analysis performed, it was possible to find correlations between the taxonomic characteristics of the genus Piper and the chemical composition of EO. In addition to registering trans-Caryophyllene as chemodiversity standard for this genus in this region. It is also the first study to compare the chemical composition of Piper arboreum Aubl. var. arboreum and Piper arboreum var. hirtelum Yunck.
\end{abstract}

Keywords: Piper, Essential Oil, monoterpenes, sesquiterpenes, Chemodiversity

\section{Introduction}

The Marambaia Island located in Southern of the Rio de Janeiro State is one of the few Atlantic Forest reserves in Southeastern Brazil. This region was very important for trade in the Brazilian colonial period, and due to the extensive degradation, nowadays it has restricted access and is an environmental protection area. ${ }^{1,2}$ In this region there is a large restinga area, and the vegetation has suffered deforestation and shows different ecological pressure compared to seasonal and ombrophilous forests. So, the conservation and study of the current plant remnants are of great importance. ${ }^{1-3}$

The genus Piper L. (Piperaceae) has a wide occurrence in Brazil. About 180 species are registered for the State of Rio de Janeiro. In the restinga vegetation of this State, there are 16 species registered as Piper. Due to the number of Piper species in restinga areas, it is permissible to propose possible indications that they may present new physiological and morphological adaptation strategies for survival in this environment, making it interesting for a chemical study. ${ }^{4-12}$

Piper species are recognized for showing ritualistic and medicinal usages, as well as aromatic plants rich in essential oils (EOs). Some of the species are medicinal recognized and of commercial importance, such as Piper nigrum L. (Black pepper), Piper methysticum Forst (Kava-kava) and P. hispidinervium C. DC. (Long pepper), while P. amalago L. (Aperta-ruão), P. mollicomum Kunth (Jaborandi-manso) and P. umbellatum L. (Capeba) are used in folk medicine. ${ }^{13-14}$ EOs from Piper species are recognized for their pharmacological properties, such as antimicrobial, antioxidant, antiparasitic, diuretic and insecticide activities. ${ }^{15-18}$ These are mainly composed of monoterpenes, sesquiterpenes, arylpropanoids and benzoic acids derivatives ${ }^{16-20}$ 
Evaluating the chemodiversity patterns of EOs derived from the chemical phenotypic plasticity of plants in different environments can significantly support the morphological analysis, understand different stimuli to environmental responses and their ecological functions. ${ }^{21-23}$ This type of approach based on the chemical compositions of the Piper EOs from the Marambaia Island has never been described before. Thus, the present study aimed to determine the chemodiversity pattern from the chemical composition of the leaf EOs of ten (10) species and two (2) varieties of Piper (Piper amalago L.; P. amplum Kunth; P. anisum (Spreng.) Angely; P. arboreum Aubl. var. arboreum; P. arboreum var. hirtelum Yunck.; P. diospyrifolium Kunth; $P$. divaricatum G. Mey.; P. gaudichaudianum Kunth; P. lepturum (Kunth) C.DC. var. lepturum; P. lepturum var. angustifolium (C.DC.) Yunck.; P. mollicomum Kunth and $P$. vicosanum Yunck.) collected in the Marambaia Island. This proposal is also based in be able to assist in a better understanding of the chemical phenotypic plasticity of the genus Piper $\mathrm{L}$.

\section{Experimental}

\subsection{Plant material}

Leaves from ten species and two varieties of Piper were collected in different areas of Marambaia Island, Mangaratiba, Rio de Janeiro, Brazil. They were collected during Spring, on November $3^{\text {rd }}, 2019$, from 9 a.m. to 12 p.m. Botanist specialist Elsie Franklin Guimarães identified the plants and herbal specimens were deposited in the Herbarium at Botanic Garden of Rio de Janeiro, Rio de Janeiro, Brazil. The location on the island and the specimen vouchers are shown in table 1 .

\subsection{Essential oil obtaining}

Fresh leaves $(150 \mathrm{~g})$ of each specimen were submitted to hydrodistillation for two hours in a modified Clevenger-type apparatus. ${ }^{24}$ The obtained EOs were separated from water and dried using anhydrous sodium sulfate (Sigma-Aldrich,
Brazil), stored in sealed amber glass vials and kept under refrigeration at $-20^{\circ} \mathrm{C}$ until analysis by gas chromatography (GC). Total EOs yielding were expressed as a percentage value $(\mathrm{g} / 100 \mathrm{~g}$ of fresh plant material).

\subsection{Essential oil analysis}

The EOs from fresh leaves were initially diluted in dichloromethane $(1 \mathrm{mg} / \mathrm{mL})$ and then submitted to analysis by GC coupled to flame ionization detector (GC-FID) and by GC coupled to mass spectrometry (GC-MS).

GC-FID analysis was performed using gas chromatograph HP-Agilent 6890 GC-FID, equipped with capillary column HP-5MS (30 m x $0.25 \mathrm{~mm}$ i.d. x $0.25 \mu \mathrm{m}$ film thickness), temperature programing from $60^{\circ} \mathrm{C}$ to $240^{\circ} \mathrm{C}$, with increasing of $3{ }^{\circ} \mathrm{C} / \mathrm{min}$, using hydrogen as carrier gas at a flow rate of $1.0 \mathrm{~mL} / \mathrm{min}$. EOs solution was injected at $1 \mu \mathrm{L}$, with injector temperature at $270{ }^{\circ} \mathrm{C}$, splitless. Retention times (tR) were measured in minutes without any correction. The relative percentage content of each compound in the mixture was obtained directly from the GC-FID analysis. ${ }^{15}$

GC-MS analysis was performed using gas chromatograph HP Agilent GC 6890 coupled to a mass spectrometer Agilent MS 5973N, with $70 \mathrm{eV}$ of ionization energy, in positive mode, capillary column HP-5MS (30 m x $0.25 \mathrm{~mm}$ i.d. x $0.25 \mu \mathrm{m}$ film thickness), temperature programing from $60{ }^{\circ} \mathrm{C}$ to $240{ }^{\circ} \mathrm{C}$, with increasing of $3{ }^{\circ} \mathrm{C} / \mathrm{min}$, using helium as carrier gas at a flow rate of $1.0 \mathrm{~mL} / \mathrm{min}$., and mass range $\mathrm{m} / \mathrm{z} 40-600$ atomic mass unit (u). EOs solution was injected at $1 \mu \mathrm{L}$, with injector temperature at $270{ }^{\circ} \mathrm{C}$, splitless. ${ }^{15}$

Retention indices (RI) were calculated using data obtained from the GC-FID of a homologous series of saturated aliphatic hydrocarbons $\left(\mathrm{C}_{8}-\mathrm{C}_{28}\right.$, Sigma-Aldrich, Brazil) carried out in the same column and conditions used in GC-FID analysis for EOs. ${ }^{25}$ The compounds identification was done by comparing the mass spectra obtained with the spectra from the equipment databases (WILEY7n; NIST), and with findings in the literature records.$^{26}$ The comparison of the calculated retention indices with the literature was used to assist on identification. All experiments were carried out in triplicate of each essential oil.

Table 1. Location and voucher for ten species and two varieties of Piper species collected in Marambaia Island, Mangaratiba, Rio de Janeiro, Brazil

\begin{tabular}{|c|c|c|c|}
\hline Code & Species & Latitude and Longitude & Voucher \\
\hline PAL & Piper amalago $\mathrm{L}$. & $23^{\circ} 03^{\prime} 37.8^{\prime \prime} \mathrm{S} 43^{\circ} 58^{\prime} 49.4^{\prime \prime} \mathrm{W}$ & RB00275754 \\
\hline PAP & Piper amplum Kunth & $23^{\circ} 03^{\prime} 34.2^{\prime \prime} \mathrm{S} 43^{\circ} 58^{\prime} 52.0^{\prime \prime} \mathrm{W}$ & RB00556846 \\
\hline PAN & Piper anisum (Spreng.) Angely & $23^{\circ} 03^{\prime} 47.3^{\prime \prime} \mathrm{S} 43^{\circ} 59^{\prime} 00.1^{\prime \prime} \mathrm{W}$ & RB01319732 \\
\hline PAA & Piper arboreum Aubl. var. arboreum & $23^{\circ} 03^{\prime} 43.0^{\prime \prime} \mathrm{S} 43^{\circ} 58^{\prime} 57.3^{\prime \prime} \mathrm{W}$ & RB00298180 \\
\hline PAH & Piper arboreum var. hirtelum Yunck & $23^{\circ} 03$ '42.9”S 4358'57.2”W & RB00302890 \\
\hline PDP & Piper diospyrifolium Kunth & $23^{\circ} 03^{\prime} 45.4^{\prime \prime} \mathrm{S} 43^{\circ} 59^{\prime} 03.0^{\prime \prime} \mathrm{W}$ & RB01319735 \\
\hline PDV & Piper divaricatum G. Mey. & $23^{\circ} 03^{\prime} 39.4^{\prime \prime} 43^{\circ} 58^{\prime} 45.7^{\prime \prime} \mathrm{W}$ & RB01319736 \\
\hline PG & Piper gaudichaudianum Kunth & $23^{\circ} 03^{\prime} 36.5^{\prime \prime} \mathrm{S} 43^{\circ} 58^{\prime} 40.3^{\prime \prime} \mathrm{W}$ & RB00299683 \\
\hline PLA & Piper lepturum var. angustifolium (C.DC.) Yunck. & $23^{\circ} 03^{\prime} 36.4^{\prime \prime} \mathrm{S} 43^{\circ} 58^{\prime} 40.8^{\prime \prime} \mathrm{W}$ & RB01319712 \\
\hline PLL & Piper lepturum (Kunth) C.DC. var. lepturum & $23^{\circ} 03^{\prime} 34.9^{\prime \prime} \mathrm{S} 43^{\circ} 58^{\prime} 51.4^{\prime \prime} \mathrm{W}$ & RB01319740 \\
\hline PM & Piper mollicomum Kunth & $23^{\circ} 03^{\prime} 36.6^{\prime \prime} \mathrm{S} 43^{\circ} 58^{\prime} 52.2^{\prime \prime} \mathrm{W}$ & RB01319730 \\
\hline PV & Piper vicosanum Yunck. & $23^{\circ} 03$ '23.9”S 4358’35.2”W & RB00564792 \\
\hline
\end{tabular}




\subsection{Chemometric analysis}

The data were analyzed using variance. Principal component analysis (PCA) and hierarchical analysis (HCA) were performed to assess the variance between the different operational taxonomic units (OTU) from chemical compositions of the EOs of each species. ${ }^{20}$ The results were processed using STATISTICA software version 10 (StartSoft Inc., Tulsa, USA).

\section{Results}

The identified compounds, retention indices, EO yields, and percentages from the ten species and two varieties of Piper are shown in Table 2. Figure 1 shows the chemical structures of the main identified compounds.

Table 2. Chemical constituents of the essential oils from leaves of 10 Piper sp. and 2 varieties obtained from Marambaia Island, Mangaratiba, Rio de Janeiro, Brazil.

\begin{tabular}{|c|c|c|c|c|c|c|c|c|c|c|c|c|c|c|}
\hline \multirow{2}{*}{ Compounds $^{\mathrm{a}}$} & \multirow{2}{*}{ RIcalc } & \multirow{2}{*}{ RIlit } & \multicolumn{12}{|c|}{ Relative peak area $(\%)$} \\
\hline & & & PAA & PAH & PAL & PAN & PAP & PDP & PDV & PG & PLA & PLL & PM & PV \\
\hline Nonane & 900 & 900 & & & & 0.13 & & & & & & & & \\
\hline$\alpha$-Thujene & 930 & 930 & & & & 0.23 & & & & & & & & \\
\hline$\alpha$-Pinene & 938 & 939 & 0.29 & 1.02 & & 1.30 & 0.46 & 3.56 & 0.39 & 0.42 & & & 7.67 & \\
\hline Camphene & 956 & 954 & & & 0.14 & & & & & & & & & \\
\hline$\beta$-Pinene & 982 & 979 & & 0.38 & & 0.17 & & 0.29 & 0.34 & & & & 6.38 & \\
\hline Myrcene & 990 & 990 & & 0.15 & & 0.53 & & & 0.31 & & 3.04 & 3.27 & 0.94 & \\
\hline$\alpha$-Phellandrene & 1006 & 1002 & & & & 7.53 & & & & & & & & \\
\hline 3-Carene & 1013 & 1011 & 4.57 & 0.19 & & & 0.52 & & & 0.53 & & & & 4.52 \\
\hline$\alpha$-Terpinene & 1013 & 1017 & & & & 8.32 & & & & & & & & \\
\hline o-Cymene & 1028 & 1026 & & 0.16 & & 0.35 & & & & 0.64 & & & & 3.78 \\
\hline Limonene & 1033 & 1029 & 0.30 & 0.18 & & 2.62 & & 1.47 & 1.50 & & & & 1.78 & \\
\hline$\beta$-cis-Ocimene & 1035 & 1037 & 5.54 & 6.85 & 2.80 & & 1.07 & 0.46 & 1.12 & 0.82 & & & & \\
\hline$\beta$-Phellandrene & 1036 & 1029 & & & & 1.28 & & & & & & & & \\
\hline 1,8-Cineole & 1037 & 1031 & & & & & & & & & & & 15.00 & 1.43 \\
\hline$\beta$-trans-Ocimene & 1049 & 1050 & 2.25 & 2.76 & 0.86 & & & & & & 0.68 & & 0.41 & \\
\hline$\gamma$-Terpinene & 1062 & 1059 & & & & 0.14 & & & & & & & 0.32 & \\
\hline Terpinolene & 1088 & 1088 & 0.66 & 1.19 & & 0.24 & & & & & & & 0.14 & \\
\hline Linalool & 1100 & 1096 & & 0.43 & 17.79 & 0.33 & 5.43 & 0.23 & & 7.43 & & & & \\
\hline cis-4,8-Dimethyl-1,3,7-nonatriene & 1115 & 1113 & 1.75 & 1.58 & & & & & & & & & & \\
\hline neo-allo-Ocimene & 1131 & 1132 & 0.73 & 0.96 & 0.30 & & & & & & & & & \\
\hline$\alpha$-Terpineol & 1197 & 1188 & & & & & & & & & & & 1.78 & \\
\hline 3,5-Dimethoxytoluene* & 1269 & 1264 & & & 0.32 & & & & & & & & & \\
\hline 2-Undecanone & 1291 & 1294 & & & & & & & & & & & 0.87 & \\
\hline$\delta$-Elemene & 1335 & 1338 & 0.72 & & 1.15 & 0.14 & & 1.32 & 0.53 & & & & & \\
\hline Bicycloelemene $^{b}$ & 1339 & & 5.28 & 1.30 & 2.29 & 1.40 & 0.74 & 0.32 & 2.69 & 1.99 & 6.96 & & 0.67 & \\
\hline$\alpha$-Cubebene & 1350 & 1351 & & 0.22 & 1.29 & 0.28 & & & 0.30 & & 0.79 & & & \\
\hline Cyclosativene & 1372 & 1371 & & & & & & 0.42 & & & & & & \\
\hline$\alpha$-Ylangene & 1372 & 1375 & & & & & & & 0.48 & & & & & \\
\hline$\alpha$-Copaene & 1378 & 1376 & 1.11 & 1.74 & 0.73 & 2.18 & 4.30 & 5.43 & 6.86 & & 0.91 & & & 12.34 \\
\hline$\beta$-Bourbonene & 1386 & 1388 & & & 0.77 & 0.18 & & & 0.94 & & & & & \\
\hline$\beta$-Cubebene & 1389 & 1388 & & & & 0.15 & & & & & & & & \\
\hline$\beta$-Elemene & 1390 & 1390 & 4.80 & 4.37 & 1.49 & 0.22 & 0.65 & 9.51 & 1.18 & 1.28 & 0.43 & & 2.48 & \\
\hline Sesquithujene & 1403 & 1405 & & & & & & & & & & 0.33 & & \\
\hline 5-Isobutyl-1,3-benzodioxole ${ }^{c}$ & 1403 & & & 0.38 & & & 1.37 & & & 1.40 & & & & \\
\hline 1-Butyl-3,4-methylenedioxybenzene ${ }^{\mathrm{d}}$ & 1408 & & & & & 58.36 & & & & & & & & \\
\hline$\alpha$-Gurjunene & 1409 & 1409 & & & & & & & & & & & 0.36 & \\
\hline$\alpha$-cis-Bergamotene & 1415 & 1412 & & & & & & & & & & 0.82 & & \\
\hline$\beta$-Ylangene & 1416 & 1420 & & & & & & & & & 0.28 & & & \\
\hline trans-Caryophyllene & 1421 & 1419 & 13.71 & 13.22 & 9.88 & 1.20 & 11.87 & 7.64 & 5.10 & 11.73 & 22.45 & 8.77 & 6.25 & 7.60 \\
\hline
\end{tabular}


Continuação...

\begin{tabular}{|c|c|c|c|c|c|c|c|c|c|c|c|c|c|c|}
\hline$\gamma$-Elemene & 1432 & 1436 & 1.05 & & 0.68 & & & 1.70 & 1.83 & 6.99 & & & 1.42 & \\
\hline$\beta$-Gurjunene & 1433 & 1433 & & 1.01 & & 0.37 & & & & & & & & \\
\hline$\alpha$-trans-Bergamotene & 1435 & 1434 & & & & 0.18 & 1.38 & 5.52 & & & 1.70 & 0.76 & & 6.18 \\
\hline Aromandendrene & 1441 & 1441 & 0.52 & 0.18 & 0.16 & 0.15 & & & 1.00 & 0.90 & 0.95 & & & \\
\hline trans-Muurola-3,5-diene & 1451 & 1453 & & 0.25 & 0.18 & & & & 0.23 & 0.98 & & & & \\
\hline$\beta$-trans-Farnesene & 1454 & 1456 & & & & 0.77 & & 0.71 & & & 3.60 & 7.73 & & \\
\hline$\alpha$-Humulene & 1458 & 1454 & 1.86 & 2.06 & 0.79 & 1.08 & 1.37 & 1.19 & 0.85 & 2.50 & 1.54 & & 2.68 & \\
\hline Cabreuva oxide B & 1462 & 1464 & & & & & & 0.82 & & & & & & \\
\hline alloAromadendrene & 1463 & 1460 & & & & & & & 0.50 & 0.66 & 0.24 & & 0.70 & \\
\hline trans-Cadina-1(6),4-diene & 1474 & 1476 & & 0.49 & & & & & 0.43 & & & & 0.54 & \\
\hline$\gamma$-Muurolene & 1477 & 1479 & 0.82 & 1.25 & 0.20 & 0.16 & & 1.39 & 3.12 & & & & & \\
\hline cis-4,10-epoxy-Amorphane & 1480 & 1479 & & & 0.37 & & & & & & & & & \\
\hline$\alpha$-Curcumene & 1483 & 1480 & & & & & & & & & & 3.36 & & \\
\hline Germacrene D & 1483 & 1481 & 9.63 & 8.32 & 1.99 & 4.92 & 2.27 & 9.73 & 24.70 & 1.57 & 1.12 & & 4.28 & 3.76 \\
\hline$\alpha$-Amorphene & 1486 & 1481 & & & & & & & & 7.50 & & & & \\
\hline$\beta$-Selinene & 1490 & 1490 & 0.64 & 0.76 & & & 5.12 & 1.03 & 0.35 & 1.20 & & & 0.43 & 8.90 \\
\hline trans-Muurola-4(14),5-diene & 1493 & 1493 & 0.98 & 0.73 & 0.37 & & & 0.42 & 2.47 & 2.69 & 0.66 & & 0.32 & \\
\hline$\beta$-cis-Guaiene & 1493 & 1493 & & & & 0.14 & & & & & & & & \\
\hline 2-Tridecanone & 1495 & 1496 & & & & & & & & & & & 0.50 & \\
\hline$\alpha$-Zingiberene & 1496 & 1493 & & & & & & & & & 7.34 & 11.10 & & \\
\hline Valencene & 1496 & 1496 & & & & & 5.02 & & & & & & & \\
\hline Viridiflorene & 1497 & 1496 & & & & & & & & & & & & 5.17 \\
\hline Bicyclogermacrene & 1497 & 1500 & 18.50 & 5.32 & 6.60 & 4.21 & & 1.75 & 8.20 & 9.46 & 17.66 & & 2.66 & \\
\hline$\alpha$-Muurolene & 1499 & 1500 & & 1.75 & 0.47 & & & 1.36 & 1.81 & & & & 0.51 & \\
\hline$\alpha$-Bulnesene & 1503 & 1509 & 0.68 & 0.88 & & & & & & & & & & \\
\hline cis,cis- $\alpha$-Farnesene & 1504 & 1505 & & & & & & & & & 0.41 & & 0.36 & \\
\hline$\beta$-trans-Guaiene & 1505 & 1502 & & & & & & 0.32 & 0.65 & & & & & \\
\hline$\beta$-Bisabolene & 1508 & 1505 & & & & & 1.78 & 3.10 & & & 1.67 & 4.69 & & 6.81 \\
\hline$\gamma$-Cadinene & 1515 & 1513 & 0.44 & 1.06 & 0.37 & & & 0.74 & 1.77 & & & & 0.40 & \\
\hline Cubebol & 1517 & 1515 & 1.85 & 1.14 & 1.71 & & & & 0.38 & & & & 0.95 & \\
\hline$\delta$-Cadinene & 1520 & 1523 & 3.81 & 6.07 & 2.40 & 0.35 & 2.99 & 2.18 & 6.20 & & 0.51 & & 2.17 & 4.34 \\
\hline 7-epi- $\alpha$-Selinene & 1521 & 1522 & & & & & & & & 29.48 & & & & \\
\hline$\beta$-Sesquiphellandrene & 1526 & 1522 & & & & & & & & & 0.99 & & & \\
\hline trans- $\gamma$-Bisabolene & 1527 & 1531 & & & & & 1.29 & 0.45 & & & 17.32 & 38.65 & & \\
\hline trans-Cadina-1,4-diene & 1535 & 1534 & & 0.39 & 0.20 & & & & 0.51 & & 0.88 & & & \\
\hline$\alpha$-Cadinene & 1539 & 1538 & & & & & & & 0.49 & & & & & \\
\hline cis- $\alpha$-Bisabolene & 1543 & 1536 & & & & & & & & & & 0.28 & & \\
\hline$\alpha$-Calacorene & 1544 & 1545 & & & & & & 0.94 & & & & & & \\
\hline Elemol & 1552 & 1549 & & 0.17 & 8.41 & & & & & & & & & \\
\hline Germacrene B & 1561 & 1561 & & & 0.37 & & & & & 3.92 & & & & \\
\hline trans-Nerolidol & 1562 & 1563 & 5.78 & 6.83 & & & 1.41 & 10.00 & 3.09 & & & & 20.54 & \\
\hline Palustrol & 1573 & 1568 & & & & & & & & & & & 0.26 & \\
\hline Caryolan-8-ol & 1578 & 1572 & & & & & & 0.39 & & & & & & \\
\hline Spathulenol & 1578 & 1579 & 1.31 & 1.55 & 3.15 & 0.24 & 0.57 & & 1.64 & & 1.14 & & 0.42 & 2.41 \\
\hline Caryophyllene oxide & 1583 & 1583 & & 0.24 & 0.90 & & 2.37 & 1.34 & 0.29 & & 0.51 & 1.37 & 0.72 & 1.65 \\
\hline Thujopsan-2- $\alpha$-ol & 1588 & 1587 & 0.79 & 0.49 & 0.29 & & & 0.99 & 1.99 & & & 0.36 & 0.53 & \\
\hline Globulol & 1595 & 1590 & & 0.17 & & & 0.62 & 1.90 & 1.20 & & & & & \\
\hline Viridiflorol & 1596 & 1592 & & & & & & & & & & & 0.10 & \\
\hline Guaiol & 1600 & 1600 & & & 13.22 & & & & 0.46 & & & & & \\
\hline
\end{tabular}




\begin{tabular}{|c|c|c|c|c|c|c|c|c|c|c|c|c|c|c|}
\hline \multicolumn{15}{|l|}{ Continuação... } \\
\hline Ledol & 1607 & 1602 & & & & & & & & & & & 1.81 & \\
\hline Rosifoliol & 1608 & 1600 & & & & & & & 0.79 & & & & & \\
\hline Khusimone & 1609 & 1604 & & & & & & 2.86 & 0.35 & & & & & \\
\hline iso-leptospermone & 1612 & 1622 & & & & & 26.44 & & & & & & & 5.43 \\
\hline Humulene epoxide II & 1612 & 1608 & & & & & & 0.36 & & & & 2.28 & 0.45 & \\
\hline$\alpha$-epi-7-epi-5-Eudesmol & 1615 & 1607 & & & 2.20 & & & & & & & & & \\
\hline Dillapiole & 1621 & 1620 & & & & & & & & & & & 2.68 & \\
\hline Di-epi-1,10-cubenol & 1623 & 1619 & 0.49 & & & & & & 0.61 & & & & & \\
\hline epi-Cedrol & 1624 & 1618 & & & & & & 0.57 & & & & & & \\
\hline 1-epi-Cubenol & 1630 & 1628 & 1.57 & 1.80 & & & & & 1.26 & & & & 0.78 & \\
\hline trans-iso-Longifolanone & 1631 & 1626 & & & 1.76 & & & 3.09 & & & & & & \\
\hline Eremoligenol & 1632 & 1631 & & & 0.77 & & 1.48 & & & & & & & \\
\hline$\gamma$-Eudesmol & 1634 & 1632 & & & & & 2.43 & & & & & & & 3.52 \\
\hline cis-Cadin-4-en-7-ol & 1637 & 1636 & & & & & & 0.63 & 0.49 & & & & & \\
\hline Gossonorol & 1640 & 1637 & & & & & & & & & 0.23 & 1.53 & & \\
\hline Caryophylla-4(12),8(13)-dien-5 $\alpha$-ol & 1641 & 1640 & & & & & & 0.84 & & & & & & \\
\hline epi- $\alpha$-Cadinol & 1645 & 1640 & 1.14 & 3.02 & & & & 0.83 & 1.49 & & 0.36 & 0.74 & 1.34 & \\
\hline epi- $\alpha$-Muurolol & 1647 & 1642 & 1.13 & 3.28 & & & & 1.10 & 1.68 & & & & 0.32 & \\
\hline$\alpha$-Muurolol & 1647 & 1646 & 2.46 & 2.51 & 1.53 & & 1.20 & 0.72 & 0.68 & & & & 0.63 & \\
\hline Cubenol & 1650 & 1646 & & & 0.44 & & & & & & & & & \\
\hline$\alpha$-Eudesmol & 1658 & 1653 & & & & & 11.57 & & & & & & & 17.35 \\
\hline$\alpha$-Cadinol & 1658 & 1654 & 2.40 & 8.89 & 2.78 & & & 2.09 & 3.39 & 1.32 & 0.21 & & 1.50 & \\
\hline neoIntermedeol & 1662 & 1660 & & & & & & 1.32 & & & & & & \\
\hline alloHimachalol & 1669 & 1662 & & & 6.15 & & & & & & & & & \\
\hline epi- $\beta$-Bisabolol & 1672 & 1671 & & & & & & & & & 2.84 & & & \\
\hline$\beta$-Bisabolol & 1674 & 1675 & & & & & & 2.05 & & & & 9.49 & & \\
\hline Apiole & 1677 & 1678 & & & & & & & & & & & 1.14 & \\
\hline epi- $\alpha$-Bisabolol & 1687 & 1684 & & & & & & 0.98 & & & & 0.81 & & \\
\hline$\alpha$-Bisabolol & 1688 & 1685 & & & & & 3.12 & 1.45 & & & & & & 4.79 \\
\hline Non-oxigenated Monoterpenes & 14.34 & 13.76 & 4.10 & 22.71 & 2.05 & 5.78 & 3.66 & 2.41 & 3.72 & 3.27 & 17.64 & 8.30 & & \\
\hline Oxigenated Monoterpenes & 0.00 & 0.43 & 17.79 & 0.33 & 5.43 & 0.23 & 0.00 & 7.43 & 0.00 & 0.00 & 16.78 & 1.43 & & \\
\hline Non-oxigenated Sesquiterpenes & 64.55 & 51.37 & 32.38 & 18.08 & 38.78 & 57.17 & 73.23 & 82.85 & 88.41 & 76.53 & 26.23 & 55.10 & & \\
\hline Oxigenated Sesquiterpenes & 18.92 & 30.09 & 43.68 & 0.24 & 51.21 & 34.33 & 19.79 & 1.32 & 5.29 & 16.58 & 30.35 & 35.15 & & \\
\hline Arylpropanoids & 0.00 & 0.38 & 0.00 & 58.36 & 1.37 & 0.00 & 0.00 & 1.40 & 0.00 & 0.00 & 3.82 & 0.00 & & \\
\hline Other Compounds & 1.75 & 1.58 & 0.32 & 0.13 & 0.00 & 0.00 & 0.00 & 0.00 & 0.00 & 0.00 & 1.37 & 0.00 & & \\
\hline Total compounds in the essential oil (\%) & 99.56 & 97.61 & 98.27 & 99.85 & 98.84 & 97.51 & 96.68 & 95.41 & 97.42 & 96.38 & 96.19 & 99.98 & & \\
\hline Oil yielding (\%) & 0.09 & 0.12 & 0.14 & 0.11 & 0.07 & 0.09 & 0.06 & 0.20 & 0.07 & 0.04 & 0.56 & 0.03 & & \\
\hline
\end{tabular}

${ }^{\mathrm{a}}$ All compounds were identified by MS and RI in accordance with experimental. ${ }^{\mathrm{a}}$ Compound listed in order of elution. RIcalc $=$ Calculated Retention Index (HP-5MS column); RIlit = Literature Retention index $\left(\right.$ Adams $\left.^{26}\right)$; Main constituents in bold. ${ }^{b}$ Identified by Shinoda et al ${ }^{66}$; ${ }^{c}$ Identified by FernándezÁlvarez et al. ${ }^{67}$; ddentified by Moreira et al. ${ }^{68} ;$ * Maybe a contaminant compound from solvent; PAA - Piper arboreum var. arboreum; PAH - P. arboreum var. hirtellum; PAL - P. amalago; PAN - P. anisum; PAP- P. amplum; PDP- P. diospyrifolium; PDV- P. divaricatum; PG - P. gaudichaudianum; PLA - P. lepturum var. angustifolium; PLL - P. lepturum var. lepturum; PM - P. mollicomum; PV - P. vicosanum.

The Piper species had an essential oil content ranging from 0.03 to $0.56 \%$ (Table 2). P. mollicomum (PM) and P. gaudichaudianum $(\mathrm{PG})$ presented the highest percentages of EOs yield $(0.56 \%$ and $0.20 \%$, respectively).

The EO from Piper species showed in total 117 compounds (Table 2). P. diospyrifolium (PDP), P. divaricatum (PDV), P. arboreum var. hirtellum (PAH) and P. mollicomum (PM) had the highest numbers ranging from 43 to 47 compounds, while other species ranged from 17 to 40 .
Piper EOs from Marambaia Island were pronounced by great relative percentage of sesquiterpenes (18.32 - 93.70\%), mainly non-oxygenated ones $(28.08-88.45 \%)$. Exception for P. anisum (PAN) which showed high levels of arylpropanoids (58.36\%), followed by PM with 3.82\%. Qualitatively, the non-oxygenated monoterpenes $\alpha$-Pinene; non-oxygenated sesquiterpenes Bicycloelemene, $\alpha$-Copaene, $\beta$-Elemene, $\alpha$-Humulene, Germacrene D and trans-Caryophyllene, as well as oxygenated sesquiterpenes Spathulenol and transCaryophyllene oxide were registered in most Piper species. 


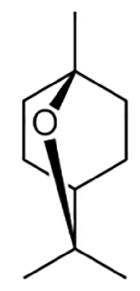

1,8-Cineole

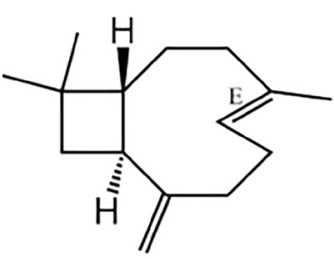

trans-Caryophyllene<smiles>CC1=CCC[C@]2(C)CC[C@@H](C(C)(C)O)C[C@H]12</smiles>

$\alpha$-Eudesmol<smiles>CC(C)=CCCC(C)=C1CC=C(C)CC1</smiles>

trans- $\boldsymbol{\gamma}$-Bisabolene<smiles></smiles>

Bicyclogermacrene<smiles>C=C(C)[C@@H]1CC[C@@]2(C)CCC=C(C)C2C1</smiles>

7-epi- $\alpha$-Selinene<smiles>CCCCc1ccc2c(c1)OCO2</smiles>

1-Butyl-3,4methylenedioxybenzene<smiles>C=CC(C)(O)CCC=C(C)C</smiles>

Linalool<smiles>C=C1/C=C\[C@H](C(C)C)CC/C(C)=C\CC1</smiles>

Germacrene D<smiles>CC1=C[C@H]2[C@@H](C(C)C)CC[C@](C)(O)[C@@H]2CC1</smiles>

$\alpha$-Cadinol<smiles>C[C@H]1CC[C@H](C(C)(O)[GeH3])CC2=C1CC[C@H](C)[C@H]2C</smiles><smiles>CCC(C)C(=O)C1=C(O)C(C)(C)C(=O)C(C)(C)C1=O</smiles>

Figure 1. Major compounds identified in essential oil of 10 Piper sp. and 2 varieties from Marambaia Island, Mangaratiba, Rio de Janeiro, Brazil

P. amalago (PAL) EO showed as major compound the oxygenated acyclic monoterpene Linalool $(17.79 \%)$ and the oxygenated bicyclic sesquiterpene Guaiol (13.22\%). P. anisum (PAN) presented an unusual compound in the EO the arylbutanoid derivative 1-Butyl-3,4-methylenedioxybenzene (58.36\%), previously described for this plant. P. amplum (PAP) showed cyclic triketone iso-leptospermone (26.44\%) and $\alpha$-Eudesmol (11.57\%). PDP EO mostly consisted of trans-Nerolidol (10.00\%), Germacrene D (9.73\%) and $\beta$-Elemene (9.51\%). PDV EO showed the monocyclic sesquiterpene Germacrene D (24.74\%). PG EO is marked by the presence of 7-epi- $\alpha$-Selinene $(29.48 \%)$; PM by the oxygenated monoterpene 1,8-Cineole $(15.00 \%)$ and P. vicosanum $(\mathrm{PV})$ by the sesquiterpenes $\alpha$-Eudesmol $(17,35 \%)$ and $\alpha$-Copaene $(12.34 \%)$.

Piper arboreum var. arboreum (PAA) and Piper arboreum var. hirtelum $(\mathrm{PAH})$ showed agreement in the presence of the major bicyclic sesquiterpene trans- Caryophyllene (13.71 and $13.22 \%)$; and significantly difference $(>5 \%)$ only in the relative percentage of Bicyclogermacrene (18.50 and 5.32\%) and $\alpha$-Cadinol (2.40 and $8.89 \%)$, respectively.
P. lepturum var. angustifolium (PLA) and P. lepturum var. lepturum (PLL) showed high relative percentage of trans- $\gamma$ Bisabolene (17.32 and 38.65\%, respectively), distinguishing their EO by the presence of Bicyclogermacrene (17.66\%) for PLA and $\beta$-Bisabolol (9.49\%) for PLL.

Some of the compounds were found to be exclusive of specific species, for example, allo-Himachalol and $\alpha$-epi-7-epi-5-Eudesmol in PAL; Valencene in PAP; 1-Butil-3,4-metilenodioxibenzene, $\alpha$-Terpinene and $\alpha$-Phellandrene in PAN; Neointermedeol and $\alpha$-calacorene in PDP; Rosifoliol and $\alpha$-Cadinene in PDV; 7-epi- $\alpha$ Selinene and $\alpha$-Amorphene in PG; epi- $\beta$-Bisabolol and $\beta$-Sesquiphellandrene in PLA; $\alpha$-Curcumene and $\alpha$-cisBergamotene in PLL; Dillapiole, Ledol and $\alpha$-Terpineol in PM, and Viridiflorene in PV.

Using the chemical profile of the majority composition ( $>5 \%$ ) of the EOs of the ten Piper sp. and two varieties from Marambaia Island, it was possible to apply chemometric analysis as shown in the heatmap in Figure 2, principal component analysis (PCA) in figure 3 and cluster analysis in figure 4. 


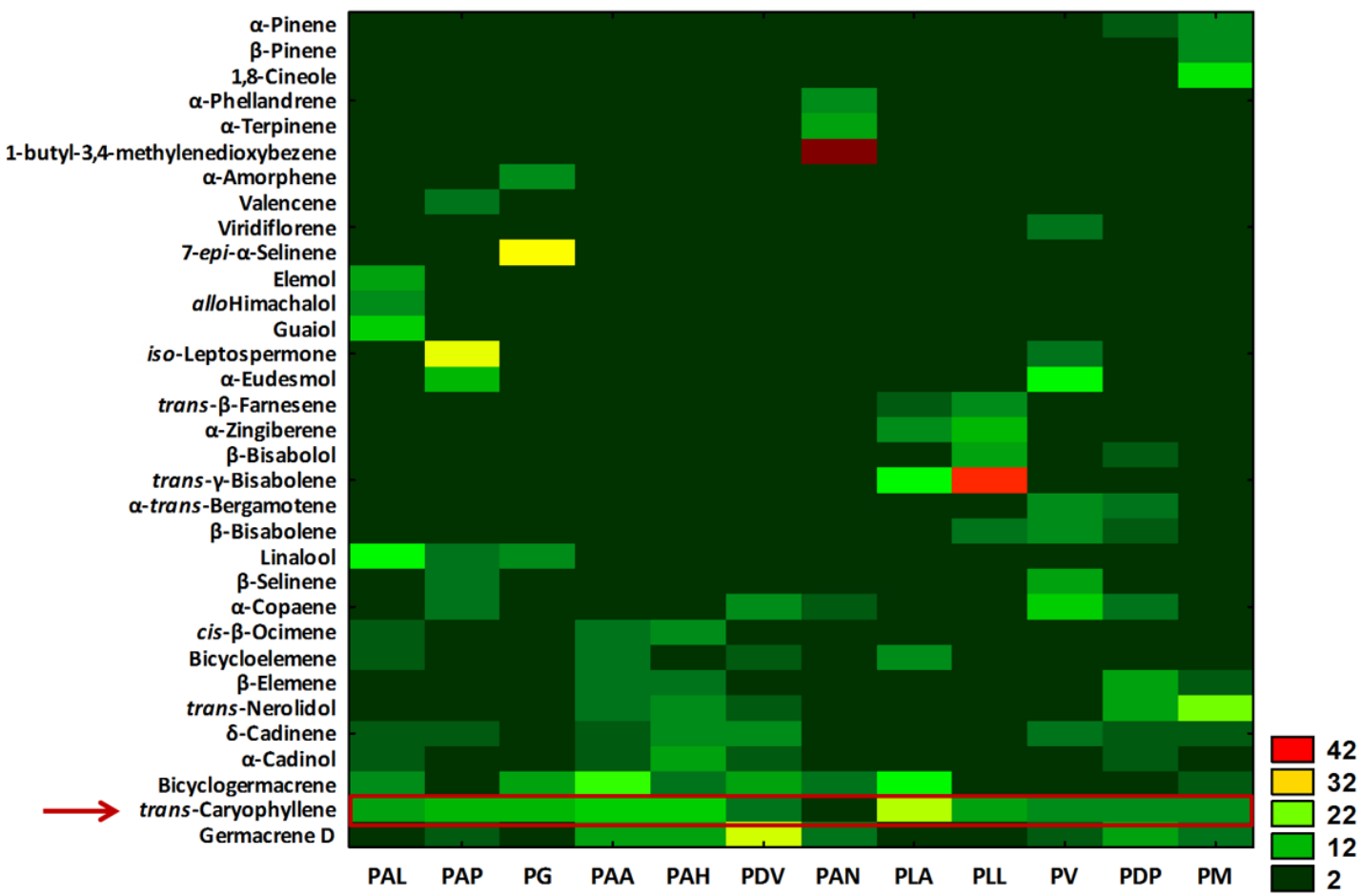

Figure 2. Heatmap (Two-Way Joining) based on the chemical profile of the samples (12 essential oils from Piper sp. obtained from Marambaia Island, Mangaratiba, Rio de Janeiro, Brazil). PAA - P. arboreum var. arboreum; PAH - P. arboreum var. hirtellum; PAL - P. amalago; PAN - P. anisum; PAP - P. amplum; PDP- P. diospyrifolium; PDV- P. divaricatum;PG - P. gaudichaudianum; PLA - P. lepturum var. angustifolium; PLL - P. lepturum var. lepturum;

$\mathrm{PM}$ - P. mollicomum; PV - P. vicosanum

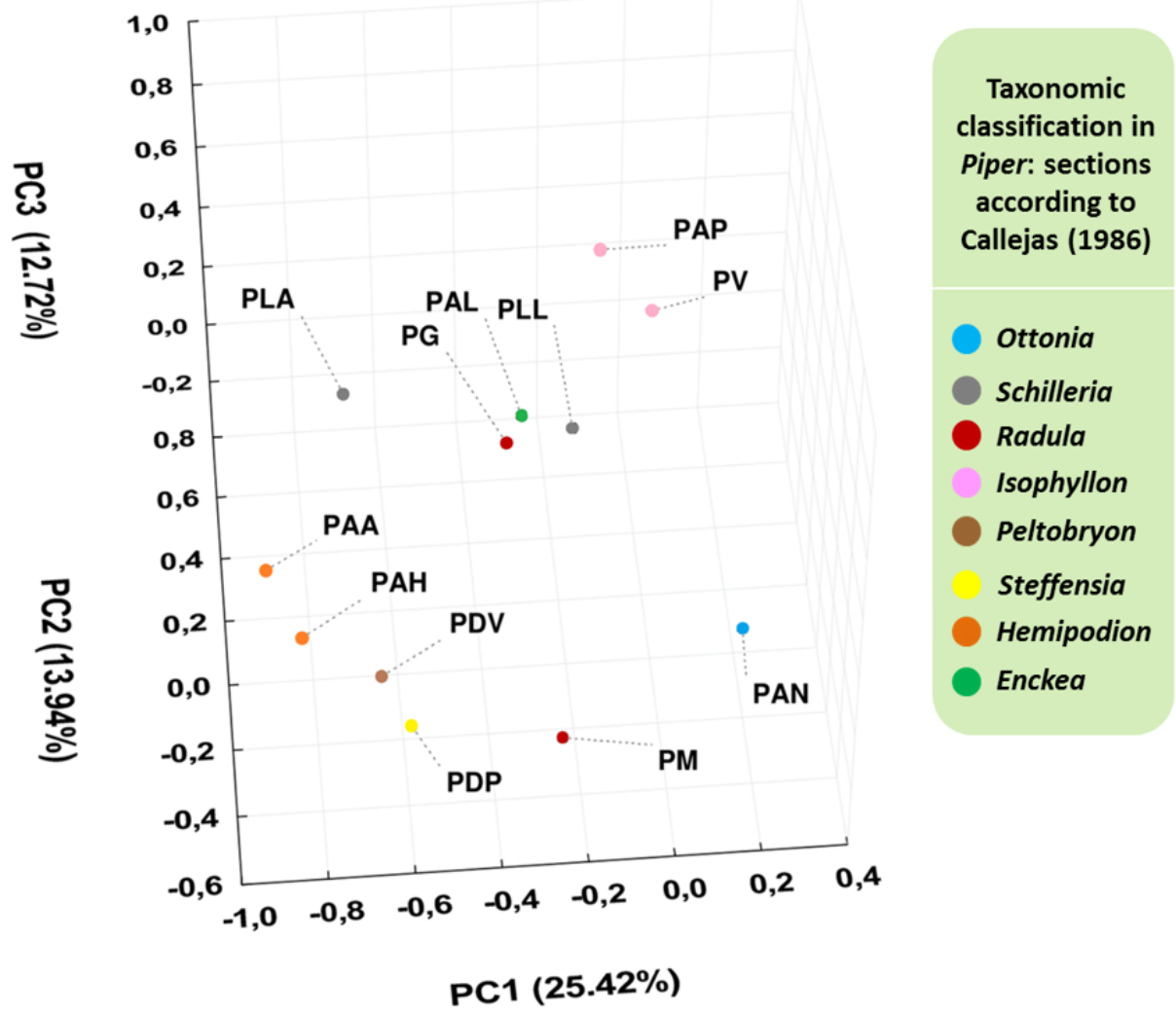

Figure 3. Triplot graph of principal component analysis based on the chemical profile of samples of 12 essential oils from Piper sp. obtained from Marambaia Island, Mangaratiba, Rio de Janeiro (Brazil), and correlated with taxonomic classification by Callejas (1986). PAA - P. arboreum var. arboreum; PAH - P. arboreum var. hirtellum; $\mathrm{PAL}-P$. amalago; $\mathrm{PAN}-P$. anisum; $\mathrm{PAP}-$ P. amplum; $\mathrm{PDP}-$ P. diospyrifolium; $\mathrm{PDV}$ - $P$. divaricatum; $\mathrm{PG}-P$. gaudichaudianum;

PLA - P. lepturum var. angustifolium; PLL - P. lepturum var. lepturum; PM - P. mollicomum; PV - P. vicosanum 


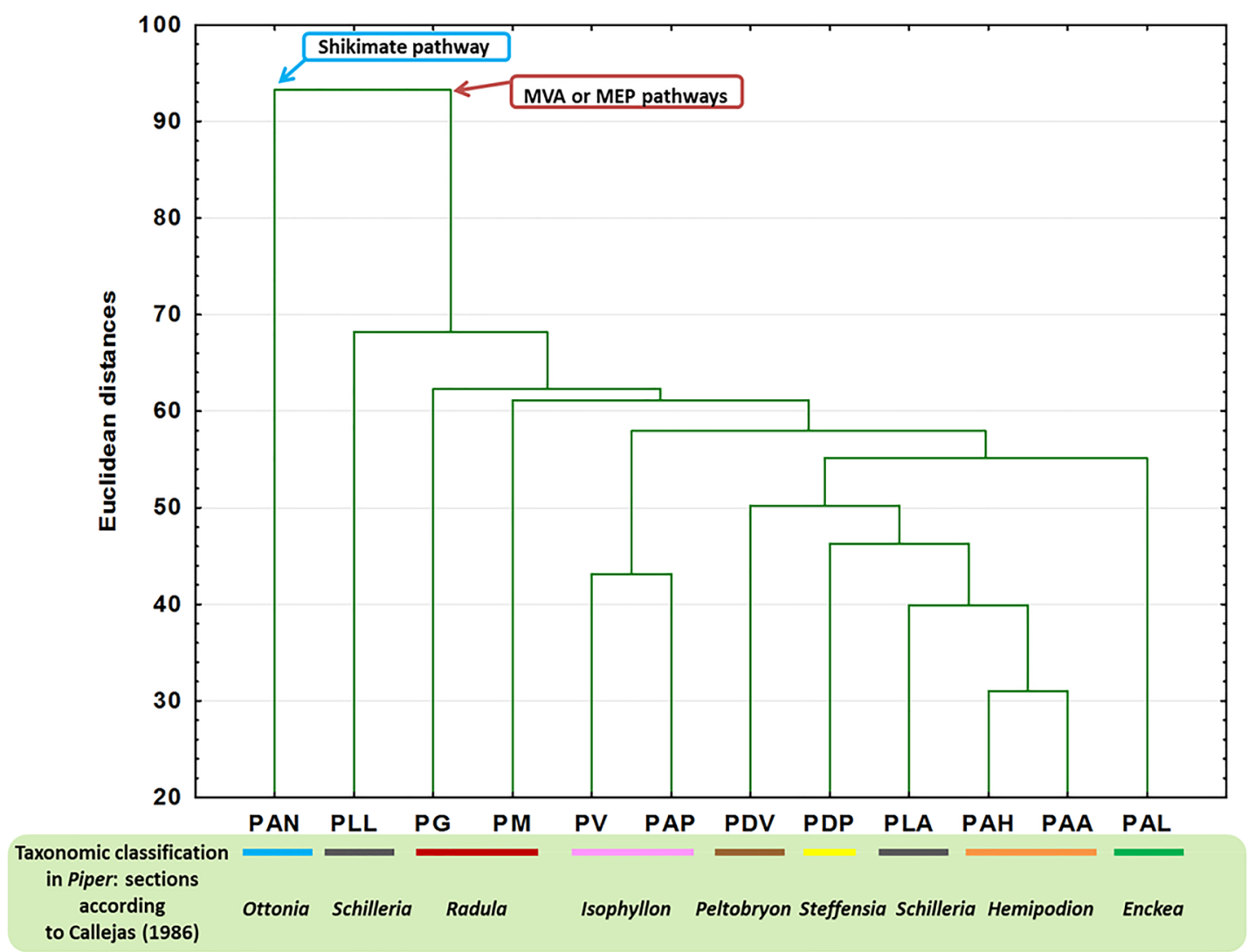

Figure 4. Cluster analysis chart based on the chemical profile of samples of 12 essential oils Piper sp. obtained from Marambaia Island, Mangaratiba, Rio de Janeiro (Brazil), and correlated with taxonomic classification by Calleja (1986). PAA - P. arboreum var. arboreum; PAH - P. arboreum var. hirtellum; $\mathrm{PAL}$ - P. amalago; PAN - P. anisum; PAP- P. amplum; PDP- P. diospyrifolium; PDV- P. divaricatum;PG - P. gaudichaudianum; PLA - P. lepturum var. angustifolium; PLL - P. lepturum var. lepturum; PM - P. mollicomum; PV - P. vicosanum

In figure 2, through color changes, a pattern of chemodiversity for the island's Piper genus based on the presence in all samples of the non-oxygenated sesquiterpene trans-Caryophyllene $(1.20-22.45 \%)$, such as a predominance of compounds from farnesyl pyrophosphate (sesquiterpenes). The species with the lowest relative percentage $(1.20 \%)$ in the $\mathrm{EO}$ was $P$. anisum, as its main compounds produced from the shikimate biosynthetic pathway. In proportion to the terpenic production in this EO, the compound has relevant value.

The compounds Germacrene D and Bicyclogermacrene are also produced by almost all species with lower percentages. This notation points out for evaluations at different time scales (seasonal and circadian) to understand the biosynthetic tendencies for the formation of humulil (trans-Caryophyllene) or germacryl (Germacrene D and Bicyclogermacrene) cations.

The results obtained in figure 3 (PCA) and 4 (Cluster) were correlated with the taxonomic classifications based on the morphology proposed by Callejas ${ }^{27}$. The main component analysis (Figure 3) was constructed in three-dimensional axis to better support the data set with a total variance of $52.08 \%$. It is possible to observe from the variance the chemical diversity presented in Piper EOs from Marambaia Island. In PC1, the negative charges of trans-Caryophyllene (-6.23), Bicyclogermacrene (-4.21) and Germacrene D (-4.19) exerted greater force for species separation.
However, PV and PAN registered positive charges on PC1 driven by the positive charge of iso-Leptospermone $(+0.737)$ and 1-Butyl-3,4-methylenedioxybenzene (+1.75), respectively. The separations in PC2 are mainly justified by the negative charges of trans-Nerolidol (-3.03) and Germacrene D (-3.00) and positive charges of trans- $\gamma$-Bisabolene $(+3.80)$ and Linalool $(+1,59)$. In PC3 the positive and negative charges that justify the separations are mainly iso-Leptospermone $(+3.66)$, $\alpha$-Eudesmol (+3.78), trans- $\gamma$-Bisabolene (-1.61), and 1-Butyl3,4-methylenedioxybezene (-1.49). Additionally, it is noted that PC1 separated the members of the Isophyllon taxonomic section (PAP and PV); PC2 separated the members (PG and PM) from the Radula taxonomic section and brought PM closer to PDP, which belongs to the Steffensia taxonomic section. However, the first three components were not sufficient to separate the varieties of $P$. lepturum (PLA and PLL).

Figure 4 (cluster) generated by the Unweighted Pair Group Methods with Arithmetic Average (UPGMA) using the Euclidean distances, it is possible to observe, from left to right, that in greater distances, there was separation of the samples that express the difference from the predominance of the different biosynthetic pathway compounds in the EOs. It was possible to register that the PAN, belonging to the Ottonia section, had the predominance of compound produced from shikimate pathway (1-Butyl-3,4-methylenedioxybenzene). 
The other species showed the production mainly of the compounds from mevalonate (MVA) or 2-C-Metileritritol 4-phosphate (MEP) pathways, mainly, high percentages of trans-Caryophyllene. Unlike the results of the PCA, complete distancing of PLL and PLA species from the Schilleria taxonomic section was observed. PLL showed exclusively high levels of trans- $\beta$-Farnesene and $\beta$-Bisabolol in comparisons with the other samples, however, this species and its variety present a composition rich in bisabolyl cation derivatives. Further study will be needed to precisely define the chemical distinctions of these species by EO or by compounds present in crude extractions or fractions (metabolomic studies).

Likewise, the Schilleria section different only due to the smaller Euclidean distance, the members of the Radula section were separated, with PG rich in 7-epi- $\alpha$-Selinene and PM rich in 1,8-Cineole. The high content of $\alpha$-Eudesmol section Isophyllon may indicate the occurrence of a chemical marker, although PAP and PV species are also rich in isoLeptospermone and $\alpha$-Copaene, respectively. The groups PDV, PDP, PLA, PAH and PAA showed to be rich in Germacrene D that led to the separation of PAL which is rich in Linalool and Guaiol. Similar to PLA and PLL, chemical convergence in the composition of EOs made it impossible to separate the $P$. arboreum varieties.

\section{Discussion}

The results showed that the EO yield values are high in relation to other commercial species, such as chamomile (Chamomilla recutita (L.) Rauschter, Asteraceae). However, compared to the yields found for species in the literature it was lower. ${ }^{20,28,29,30-32}$ It is known that EOs are associated with communication between plants, in attracting pollinators and seed disseminators and in defense against other plants, microorganisms and herbivory. In addition, several factors interfere in the qualitative and quantitative production of essential oils. ${ }^{33,34}$ These changes are associated with the genotype of the species that, throughout the evolutionary process, made several plastic adaptations, enabling greater variations in EOs because of interactions with biotic and edaphoclimatic factors, such as seasonal and circadian rhythms modulations due to water availability, nutrition, and air pollution. . $^{35,36}$

The range in which temperature variations occur is one of the factors that most influence the development of the species, thus affecting the production of secondary metabolites. The formation of volatile oils, in general, seems to increase at higher temperatures, although very hot days lead to an excessive loss of these metabolites. In addition, water stress and saline soils, typical of restingas, often have significant consequences on the qualitative and quantitative yields of secondary metabolites in plants. There are several reports that these conditions generally lead to an increase in the production of various types of secondary metabolites. ${ }^{34-36}$
The Marambaia Island, mainly in the restinga area, has a rainy tropical climate, with the air temperatures in the region typical of tropical coastal areas. ${ }^{2}$ The monthly average temperatures are higher in relation to dense and stationary rain forests. In November, when the plants were collected, the average temperature was $24.5^{\circ} \mathrm{C}$. These factors may be related to the low yields found in the species of Piper in this area.

Many of the identified compounds are used in the pharmaceutical and cosmetic industry, presenting promising results and applications, for example, trans- $\gamma$-Bisabolene is used for the development of antiperspirants and deodorants. ${ }^{37}$ trans-Caryophyllene is an important antioxidant component of many EOs used as seasoning. ${ }^{37}$ Compound $\alpha$-Pinene, a common constituent of several EOs, is used in the manufacture of insecticides and solvents; $\alpha$-Terpinene shows antimicrobial and antifungal action. ${ }^{38}$ The arylbutanoid derivative, 1-Butyl3,4-methylenedioxybenzene, the main compound of $P$. anisum $\mathrm{EO}$, has larvicidal activity ${ }^{39,68}$, and Linalool which is widely used in the food and cosmetics industry, known for its antimicrobial and parasitic properties. ${ }^{40,41}$

For the first time it was identified as the majority 7-epi$\alpha$-Selinene in PG ${ }^{42-48}$, Linalool and Guaiol in PAL ${ }^{42,43,49-52}$, Germacrene D in $\mathrm{PDV}^{53}$, and $\alpha$-Eudesmol in PV ${ }^{54,55}$. However, the findings for PAN, PDP, PLA, PLL and PM were similar to that described in the literature..$^{20,31,39,42-59}$ We emphasize that PM has not presented until this report any content of arylpropanoids in the leaves, only in inflorescences and infructescences such as described before by our group. ${ }^{20}$

We highlight that, for the first time, the majority presence of iso-Leptospermone in the EOs of the genus Piper (PAL and PV). This compound is naturally occurring in EOs in the species of basal angiosperms. ${ }^{60,61}$ The hypothesis is that chemical production may be related to the process of chemical convergence, in the evolutionary histories of the species PAL and PV, which are already very close morphologically and belong to the same taxonomic section (Isophyllon).

Some authors already described importance of chemical phenotypic plasticity as a tool to elucidate phylogenetic relationships, mainly from descriptions of the matrix of natural products of a given taxon, and use them for a phenetic characterization of clades, mainly in EOs. ${ }^{22,23,62,63}$ There are great difficulties in having secondary metabolites as markers. In many studies, the mixture of compounds may show chemical agreement and divergence in relation to the taxonomic groups. It is known that these changes are due to the different pressures and adaptations to the abiotic and biotic factors acquired over the evolution of the species in their environment. ${ }^{23}$ This could justify in general the maintenance of chemical production by some biosynthetic pathways for varieties in P. arboreum (PAH and PAA), as well as for P. lepturum (PLL and PLA). According to Machado and collaborators ${ }^{64}$ Piper species are difficult to define because they are very similar in their external morphology, making their identification difficult. 
The emergence of variation within taxon makes this challenge even more difficult. Pereira et al. ${ }^{31}$ in their work tried to differentiate EOs from PLL and PLA collected in the city of Rio de Janeiro (Rio de Janeiro, Brazil). Authors observed that PLL showed higher percentage of $\alpha$-Guaiene and PLA presented $\beta$-Bisabolene. This fact was not reported on Marambaia Island, in which conservation of precursors was reported. We suggest a deeper ecological chemical approach to differentiation, and we emphasize that it was possible by anatomical and histochemical analysis to differentiate these species. ${ }^{64}$

Light is shed for chemical plasticity presented in the Ottonia (PAN) section, and the shikimate derivatives in EOs may be an interesting chemical marker for the evaluation and identification of this species. We believe that more in-depth evaluations around the understanding of phenoplasticity with species in this section should be performed at different spatial and temporal scales to confirm this hypothesis.

The presence of trans-Caryophyllene as marked in Piper may be important in the process of chemical communication for the genus in Marambaia Island. However, it needs to be better evaluated. It is known that deciphering chemodiversity patterns is a current challenge in ecological chemical studies, as these exist and are important for the maintenance and survival of species in their natural environment. Kessler and Kalske $^{21}$ describe that the more common, or more apparent, a species is in its community, the less noise should impact its communication systems. In addition, the strength of natural selection in chemical communication by antagonists should increase the more dominant a species becomes. For better understanding, trans-Caryophyllene together with Limonene, Linalool and Arylpropanoid derivatives make up about $50-70 \%$ of the floral emissions of all studies, serving as an indicator to define this marker, highlights the importance of this study. ${ }^{21,65}$ However, a future study of the seasonality in the area will be important to better analyze the changes in the chemical compositions of the Piper species from the Marambaia Island.

\section{Conclusions}

This is the first study on the chemical composition of the EOs of Piper species from Marambaia Island, Rio de Janeiro. Nineteen monoterpene compounds and 89 sesquiterpene compounds were identified, showing an important chemical diversity. It is also the first known study comparing the chemical composition of the EOs from the leaves of $P$. arboreum varieties. Also, this study registered unprecedented detection of the major compound in $P$. gaudichaudianum, $P$. amalago, $P$. divaricatum and $P$. viscosanum, in addition to reporting the existence of arylpropanoids for the first time in the EO of P. mollicomum from leaves. It was permissible to describe trans-Caryophyllene as a possible chemical marker to decode Piper chemodiversity on the Island. Important correlations between sections and the chemical composition of EOs were achieved for Piper species from Marambaia, bringing some light to chemotaxonomic features in Piperaceae.

\section{Acknowledgements}

The authors thank CAPES, FAPERJ, PROEP-CNPq for their financial support, and the Brazilian Navy for their support and accomodations.

\section{References}

1. Pereira,M. G.; Menezes, L.F.T.D.; Schultz, N.; Aporte e decomposição da serapilheira na Floresta Atlântica, Ilha da Marambaia, Mangaratiba, RJ. Ciência Florestal 2008, 18, 443. [CrossRef]

2. Goncalves, N. B.; Nettesheim, F. C.; Conde, M.; Tree community variation in a tropical continental island according to slope aspect and human interference. Anais da Academia Brasileira de Ciências 2018, 90, 17. [CrossRef] [PubMed]

3. Lourenço, E. C.; Costa, L. M.; Silva, R. M.; Esbérard, C. E. L.; Bat diversity of Ilha da Marambaia, Southern Rio de Janeiro State, Brazil (Chiroptera, Mammalia). Brazilian Journal of Biology 2010, 70, 511. [CrossRef] [PubMed]

4. Yuncker, T. G.; The Piperaceae of Brazil. Hoehnea 1972, $2,19$.

5. Guimarães, E. F.; Mautone, L.; Magalhães, H. G.; Guimarães, L. A.; Estudos taxonômico e farmacoquímico e bioensaios de Piper lhotzkyanum Kunth (Piperaceae), uma espécie ocorrente em Minas Gerais. Daphne 1992, 2, 3. [Link]

6. Tebbs, M. C. Piperaceae.; In: Flowering Plants. Dicotyledons. Springer, Berlin, Heidelberg 1993, 516. [CrossRef]

7. Jaramillo, M. A.; Manos, P. S.; Phylogeny and patterns of floral diversity in the genus Piper (Piperaceae). American Journal of Botany 2001, 88, 706. [CrossRef] [PubMed]

8. Chase, M. W.; Christenhusz, M. J. M.; Fay, M. F.; Byng, J. W.; Judd, W. S.; Soltis, D. E.; Stevens, P. F.; An update of the Angiosperm Phylogeny Group classification for the orders and families of flowering plants: APG IV. Botanical Journal of the Linnean Society 2016, 181, 1. [CrossRef]

9. Queiroz, G. A.; Guimarães, E. F.; Piper L.(Piperaceae) do Leste Metropolitano, RJ, Brasil. Brazilian Journal of Development 2020, 6,11 . [CrossRef]

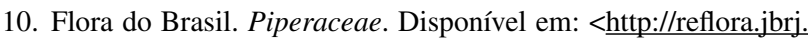
gov.br/reflora/floradobrasil/FB190>. Acesso em 05 fev. 2021.

11. Weng, J. K.; Philippe, R. N.; Noel, J. P.; The rise of chemodiversity in plants. Science 2012, 336, 1667. [CrossRef] [PubMed]

12. Müller, C.; Bräutigam, A.; Eilers, E.; Junker, R.; Schnitzler, J. P.; Steppuhn, A.; Wittmann, M.; Ecology and evolution of intraspecific chemodiversity of plants. Research Ideas and Outcomes 2020, 6, e49810. [CrossRef] [PubMed]

13. Fonseca-Kruel, V. S.; Peixoto, A. L.; Ethnobotany of Arraial do Cabo Marine Extractive Reserve, Rio de Janeiro, Brazil. Acta Botanica Brasilica 2004, 18, 177. [CrossRef]

14. Gilbert, B.; Favoreto, R.; Piper umbellatum L.= Pothomorphe umbellata (L.) Miq. Revista Fitos, 2010, 5, 2. [Link]

15. Oliveira, G. L.; Moreira, D. D. L.; Mendes, A. D. R.; Guimarães, E. F.; Figueiredo, L. S.; Kaplan, M. A. C.; Martins, E. R.; Growth study and essential oil analysis of Piper aduncum from two sites of Cerrado biome of Minas Gerais State, Brazil. Revista Brasileira de Farmacognosia 2013, 23, 743. [CrossRef] 
16. Silva, J. K.; Trindade, R.; Alves, N. S.; Figueiredo, P. L.; Maia, J. G. S.; Setzer, W. N.; Essential oils from neotropical Piper species and their biological activities. International Journal of Molecular Sciences 2017, 18, 2571. [CrossRef] [PubMed]

17. Salehi, B.; Zakaria, Z. A.; Gyawali, R.; Ibrahim, S. A.; Rajkovic, J.; Shinwari, Z. K.; Setzer, W. N.; Piper species: A comprehensive review on their phytochemistry, biological activities and applications. Molecules 2019, 24, 1364. [CrossRef] [PubMed]

18. Fonseca, A. C. C. D.; de Queiroz, L. N.; Sales Felisberto, J.; Ramos, Y. J.; Mesquita Marques, A.; Wermelinger, G. F.; Robbs, B. K.; Cytotoxic effect of pure compounds from Piper rivinoides Kunth against oral squamous cell carcinoma. Natural Product Research 2020, 10, 1. [CrossRef] [PubMed]

19. Silva Novaes, A.; Silva Mota, J.; Barison, A.; Veber, C. L.; Negrão, F. J.; Kassuya, C. A. L.; Barros, M. E.; Diuretic and antilithiasic activities of ethanolic extract from Piper amalago (Piperaceae). Phytomedicine 2014, 21, 523. [CrossRef] [PubMed]

20. Ramos, Y. J.; Brito Machado, D.; Queiroz, G. A.; Guimarães, E. F.; Defaveri, A. C. A.; Moreira, D. L.; Chemical composition of the essential oils of circadian rhythm and of different vegetative parts from Piper mollicomum Kunth-A medicinal plant from Brazil. Biochemical Systematics and Ecology 2020, 92, 104116. [CrossRef]

21. Kessler, A.; Kalske, A. Plant secondary metabolite diversity and species interactions.; Annual Review of Ecology, Evolution, and Systematics 2018, 49, 115. [CrossRef]

22. Zidorn, C.; Plant chemophenetics - A new term for plant chemosystematics/plant chemotaxonomy in the macro-molecular era. Phytochemistry 2019, 163, 147. [CrossRef]

23. Sadgrove, N. J.; Telford, I. R.; Padilla-González, G. F.; Greatrex, B. W.; Bruhl, J. J.; GC-MS 'chemophenetics' on Australian pinkflowered Phebalium (Rutaceae) using herbarium leaf material demonstrates phenetic agreement with putative new species. Phytochemistry Letters 2020, 38, 112. [CrossRef]

24. Wasicky, R.; Uma modificação do aparelho de Clevenger para extração de óleos essenciais. Revista Faculdade de Farmácia e Bioquímica 1963, 1, 77.

25. Dool, H. V. D.; Kratz, P. D.; A generalization of retention index system including linear temperature programmed Gas-Liquid Partition Chromatogaphy. Journal of Chromatography 1963, 11, 463. [CrossRef] [PubMed]

26. Adams, R. P.; Identification of essential oil components by gas chromatography/quadrupole mass spectroscopy. 4a. ed., Carol Stream: Illinois, 2007.

27. Callejas, R.; Taxonomic revision of Piper subgenus Ottonia (Piperaceae). Tese de Doutorado. City University of New York, 1986.

28. Navickiene, H. M. D.; Morandim, A. D. A.; Alécio, A. C.; Regasini, L. O.; Bergamo, D. C. B.; Telascrea, M.; Kato, M. J.; Composition and antifungal activity of essential oils from Piper aduncum, Piper arboreum and Piper tuberculatum. Química Nova 2006, 29, 467. [CrossRef]

29. de BF Ferraz, A.; Balbino, J. M.; Zini, C. A.; Ribeiro, V. L. S.; Bordignon, S. A.; von Poser, G.; Acaricidal activity and chemical composition of the essential oil from three Piper species. Parasitology Research 2010, 107, 243. [CrossRef] [PubMed]
30. Simeone, M. L. F.; Mikich, S. B.; Côcco, L. C.; Hansel, F. A.; Bianconi, G. V.; Chemical composition of essential oils from ripe and unripe fruits of Piper amalago L. var. medium (Jacq.) Yunck and Piper hispidum Sw. Journal of Essential Oil Research 2011, 23, 54. [CrossRef]

31. Pereira, F. G.; Santos, P. R. D.; Guimarães, E. F.; Kaplan, M. A. C.; Composition of the essential oils from leaves of Piper lepturum Kunth (C. DC.) var. lepturum and Piper lepturum var. angustifolium (Miq.) Yunck. from Brazil. Boletín Latinoamericano y del Caribe de Plantas Medicinales y Aromáticas 2016, 15, 88. [Link]

32. Schindler, B.; Silva, D. T.; Heinzmann, B. M.; Efeito da sazonalidade sobre o rendimento do óleo essencial de Piper gaudichaudianum Kunth. Ciência Florestal 2018, 28, 263. [CrossRef]

33. Nalepa, T.; Carvalho, R. I. N.; Produção de biomassa e rendimento de óleo essencial em camomila cultivada com diferentes doses de cama-de-aviário. Scientia Agraria 2007, 8, 161. [Link]

34. Gobbo-Neto, L.; Lopes, N. P.; Plantas medicinais: fatores de influência no conteúdo de metabólitos secundários. Química Nova 2007, 30, 374. [CrossRef]

35. Schwob, I.; Bessiere, J. M. Masotti V. V.; Viano J. J.; Changes in essential oil composition in saint john, $\mathrm{s}$ wort (Hypericum perforatum L.) aerial parts during its phonological cycle. Biochemical Systematics and Ecology 2004, 32, 735. [CrossRef]

36. Pritarević, I.; Kuftinec, J.; Blažević, N.; Kuštrak, D.; Seasonal variation of essential oil yield and composition of dalmatian sage, Salvia officinalis. Journal of Natural Products 1984, 47, 409. [CrossRef] [PubMed]

37. Cosentino, S.; Tuberoso, C. I. G.; Pisano, B.; Satta, M.; Mascia, V.; Arzedi, E; Palmas, F.; In-vitro antimicrobial activity and chemical composition of Sardinian Thymus essential oils. Letters in Applied Microbiology 1999, 29, 130. [CrossRef] [ubMed]

38. Sibanda, S.; Chigwada, G.; Poole, M.; Gwebu, E. T.; Noletto, J. A.; Schimidt, J. M.; Rea, A. I; Satzer, W. N.; Composition and bioactivity of the leaf essential oil of Heteropyxis dehniae from Zimbabwe. Journal of Ethnopharmacology 2004, 92, 107. [CrossRef] [PubMed]

39. Batista, D.; Campos, P.; Silva, V. R.; Santos, L. D. S.; Bezerra, D. P.; Soares, M. B.; Ribeiro, P. R.; Piper anisum as a promising new source of bioactive metabolites. Chemical Papers 2020, 74, 1505. [CrossRef $]$

40. Letizia, C. S.; Cocchiara, J.; Lalko, J.; Api, A. M.; Fragrance material review on linalool. Food and Chemical Toxicology $\mathbf{2 0 0 3}$ 41, 943. [CrossRef] [PubMed]

41. Villamizar, L. H.; Cardoso, M. D. G.; Andrade, J. D.; Teixeira, M. L.; Soares, M. J.; Linalool, a Piper aduncum essential oil component, has selective activity against Trypanosoma cruzi trypomastigote forms at $4{ }^{\circ} \mathrm{C}$. Memórias do Instituto Oswaldo Cruz 2017, 112, 131. [CrossRef] [PubMed]

42. Perigo, C. V.; Torres, R. B.; Bernacci, L. C.; Guimarães, E. F.; Haber, L. L.; Facanali, R.; Vieira, M. A. R.; Quecini, V.; Marques, M. O. M.; The chemical composition and antibacterial activity of eleven Piper species from distinct rainforest areas in Southeastern Brazil. Industrial Crops and Products 2016, 94, 528. [CrossRef] 
43. Morandim-Giannetti, A. A.; Pin, A. R.; Pietro, N. A.S.; Oliveira, H. C.; Mendes-Giannini, M. J. S.; Alecio, A. C.; Kato, M. J.; Oliveira, J. E.; Furlan, M.; Composition and antifungal activity against Candida albicans, Candida parapsilosis, Candida krusei and Cryptococcus neoformans of essential oils from leaves of Piper and Peperomia species. Journal of Medicinal Plant Research 2010, 4, 1810. [Link]

44. Bernuci, K. Z.; Iwanaga, C. C.; Fernadez-Andrade, C. M.; Lorenzetti, F. B.; Torres-Santos, E. C.; Faiões, V. D.; Gonçalves, J. E.; Amaral, W.; Deschamps, C.; Scodro, R. B.; Cardoso, R. F.; Evaluation of chemical composition and antileishmanial and antituberculosis activities of essential oils of Piper species. Molecules 2016, 21, 1698. [CrossRef] [PubMed]

45. Andrade, E. H.; Zoghbi, M. D.; Santos, A. S.; Maia, J. G.; Essential oils of Piper gaudichaudianum Kunth and P. regnellii (Miq.) C.DC. Journal of Essential Oil Research 1998, 10, 465. [CrossRef]

46. Morais, S. M.; Facundo, V. A.; Bertini, L. M.; Cavalcanti, E. S.; dos Anjos Júnior, J. F.; Ferreira, S. A.; de Brito, E. S.; de Souza Neto, M. A.; Chemical composition and larvicidal activity of essential oils from Piper species. Biochemical Systematics and Ecology 2007, 35, 670. [CrossRef]

47. Péres, V. F.; Moura, D. J.; Sperotto, A. R. M.; Damasceno, F. C.; Caramão, E. B.; Zini, C. A.; Saffi, J.; Chemical composition and cytotoxic, mutagenic and genotoxic activities of the essential oil from Piper gaudichaudianum Kunth leaves. Food and Chemical Toxicology 2009, 47, 2389. [CrossRef] [PubMed]

48. Sperotto, A. R. M.; Moura, D. J.; Péres, V. F.; Damasceno, F. C.; Caramão, E. B.; Henriques, J. A. P.; Saffi, J.; Cytotoxic mechanism of Piper gaudichaudianum Kunth essential oil and its major compound nerolidol. Food and Chemical Toxicology 2013, 57, 57. [CrossRef] [PubMed]

49. Potzernheim, M.; Bizzo, H. R.; Agostini-Costa, T. S.; Vieira, R. F.; Carvalho-Cilva, M.; Gracindo, L. A. M. B.; Chemical characterization of seven Piper species (Piperaceae) from Federal District, Brazil, based on volatile oil constituents. Revista Brasileira de Plantas Medicinais 2006, 8, 10. [Link]

50. Setzer, W. N.; Park, G.; Agius, B. R.; Stokes, S. L.; Walker, T. M.; Haber, W. A.; Chemical compositions and biological activities of leaf essential oils of twelve species of Piper from Monteverde, Costa Rica. Natural Product Communications 2008, 3, 1367. [CrossRef]

51. de Ferraz, A. B. F.; Balbino, J. M.; Zini, C. A.; Ribeiro, V. L.; Bordignon, S. A.; Von-Poser, G.; Acaricidal activity and chemical composition of the essential oil from three Piper species. Parasitology Research 2010, 107, 243. [CrossRef] [PubMed]

52. Mota, J. S.; Souza, D. S.; Boone, C. V.; Lima Cardoso, C. A.; Bastos Caramão, E.; Identification of the volatile compounds of leaf, flower, root and stem oils of Piper amalago (Piperaceae). Journal of Essential Oil Bearing Plants 2013, 16, 11. [CrossRef]

53. Almeida, J. G. L.; Silveira, E. R.; Pessoa, O. D. L.; Nunes, E. P.; Essential oil composition from leaves and fruits of Piper divaricatum G. Mey. Journal of Essential Oil Research 2009, 21, 228. [CrossRef]

54. Brait, D. R.; Vaz, M. S.; Arrigo, J. S.; Carvalho, L. N.; Araújo, F. H.; Vani, J. M.; da Mota, J. S.; Cardoso, C. A.; Oliveira, R. J.; Negrão, F. J.; Toxicological analysis and anti-inflammatory effects of essential oil from Piper vicosanum leaves. Regulatory Toxicology and Pharmacology 2015, 73, 699. [CrossRef]
55. Mesquita, J. M. O.; Oliveira, A. B.; Braga, F. C.; Lombardi, J. A.; da Cunha, A. P.; Salgueiro, L.; Cavaleiro, C.; Essential oil constituents of Piper vicosanum Yunker from the Brazilian Atlantic forest. Journal of Essential Oil Research 2006, 18, 392. [CrossRef]

56. Vieira, S. C.; Paulo, L. F.; Svidzinski, T. I.; Dias Filho, B. P.; Nakamura, C. V.; Souza, A. D.; Young, M. C.; Cortez, D. A.; Antifungal activity of Piper diospyrifolium Kunth (Piperaceae) essential oil. Brazilian Journal of Microbiology 2011, 42, 1001. [CrossRef] [ubMed]

57. Morandim, A. D.; Pin, A. R.; Pietro, N. A.; Alecio, A. C.; Kato, M. J.; Young, C. M.; de Oliveira, J. E.; Furlan, M.; Composition and screening of antifungal activity against Cladosporium sphaerospermum and Cladosporium cladosporioides of essential oils of leaves and fruits of Piper species. African Journal of Biotechnology 2010, 9, 6135. [Link]

58. Duarte, M. C. T.; Leme, E. E.; Delarmelina, C.; Soares, A. A.; Figueira, G. M.; Sartoratto, A.; Activity of essential oils from Brazilian medicinal plants on Escherichia coli. Journal of Ethnopharmacology 2007, 111, 197. [CrossRef] [PubMed]

59. Souza, S. P.; Valverde, S. S.; Costa, N. F.; Calheiros, A. S.; Lima, K. S. C.; Frutuoso, V. S.; Lima, A. L. S.; Chemical composition and antinociceptive activity of the essential oil of Piper mollicomum and Piper rivinoides. Journal of Essential Oil Research 2014, 8, 788. [Link]

60. Alvarez Costa, A.; Naspi, C. V.; Lucia, A.; Masuh, H. M.; Repellent and larvicidal activity of the essential oil from Eucalyptus nitens against Aedes aegypti and Aedes albopictus (Diptera: Culicidae). Journal of Medical Entomology 2017, 54, 670. [CrossRef] [PubMed]

61. Christoph, F.; Kubeczka, K. H.; Stahl-Biskup, E.; The composition of commercial manuka oils from New Zealand. Journal of Essential Oil Research 1999, 11, 705. [CrossRef]

62. Evergetis, E.; Haroutounian, S. A.; Volatile systemtics: A novel biochemical interpretation of essential oil compounds enhances their chemophenetic significance. Biochemical Systematics and Ecology 2020, 92, 104087. [CrossRef]

63. Nikolić, J. S.; Zlatković, B. K.; Jovanović, S. Č.; Stojanović, G. S.; Marin, P. D.; Mitić, Z. S.; Needle volatiles as chemophenetic markers in differentiation of natural populations of Abies alba, A. $x$ borisii-regis and A. cephalonica. Phytochemistry 2021, 183, 112612. [CrossRef] [PubMed]

64. Machado, N. S. D. O.; Pereira, F. G.; Santos, P. R. D. D.; Costa, C. G.; Guimarães, E. F.; Comparative anatomy of the leaves of Piper lepturum (Kunth) C. DC. var. lepturum and Piper lepturum var. angustifolium (C. DC.) Yunck. Hoehnea. 2015, 42, 1. [CrossRef]

65. Knudsen, J. T.; Eriksson, R.; Gershenzon, J.; Ståhl, B.; Diversity and distribution of floral scent. The Botanical Review 2006, 72 , 1. [CrossRef]

66. Shinoda, N.; Shiga, M.; Nishimura, K.; Constituents of yuzu (Citrus junos) oil. Agricultural and Biological Chemistry 1970, 34, 2. [CrossRef]

67. Fernández-Álvarez, M.; Lores, M.; Llompart, M.; García-Jares, C.; Cela, R.; The photochemical behaviour of five household pyrethroid insecticides and a synergist as studied by photo-solidphase microextraction. Analytical and Bioanalytical Chemistry 2007, 388, 5 [ CrossRef] [PubMed] 
68. Moreira, D. L.; Kaplan, M. A. C.; Guimarães, E. F.; 1-Butyl-3, 4-methylenedioxybenzene as the major constituent of essential oil from Ottonia anisum Sprengel (Piperaceae). Journal of Essential Oil Research 1997, 9, 5. [CrossRef] 